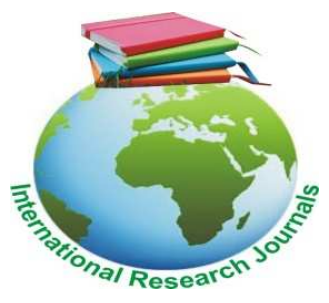

Educational Research (ISSN: 2141-5161) Vol. 8(1) pp. 001-005, January, 2017

Available online@ http://www.interesjournals.org/ER

DOI: http:/dx.doi.org/10.14303/er.2017.016

Copyright (C) 2017 International Research Journals

Review

\title{
Management of Diversification at the Senior Secondary Education level in Nigeria by the School Administrators
}

\author{
Paul Nwakpa \\ Department of Educational Foundations, Faculty of Education, Ebonyi State University, Abakaliki, Nigeria \\ Corresponding Author's E-mail: bropaulnwaoo@gmail.com
}

\begin{abstract}
This Paper focused on management of diversification at the senior secondary education level in Nigeria. Secondary education has been described as the second in the tripot of education. It serves as a bridge between the primary education and tertiary education. The two major aims of secondary education are: preparing the recipients for higher education and preparing the recipients for useful living within the society. The paper went further to $x$-ray some diversifications that could be explored in order to achieve fully the aims of senior secondary education to include: full utilization of the available human resources; provision and full utilization of financial resources; provision and full utilization of material resources; full and proper use of time resource full utilization of alternative sources of funds, provision of adequate instructional and personnel supervision, strict adherence to adoption of the principle of division of labour and specialization, adoption of the principle of leadership by example, adoption of the principle of reward and punishment moral-re-orientation, curriculum expansion and implementation. The paper finally concludes a wholesale adoption of the discussed diversifications for easy achievement of the aims of secondary education.
\end{abstract}

Keywords: Diversification, Management, Education, Adoption, Secondary education

\section{INTRODUCTION}

Secondary education has been described as the, second in the tripot of education. The first and the third being primary and tertiary education. Secondary education serves as a bridge between the primary schools and tertiary institutions.

The Federal Government of Nigeria in the National Policy on Education (2004) stated two basic aims or goals of secondary education, these are:

(a) Preparing the recipients for higher education and

(b) Preparing the recipients for useful living within the society (Job).

These two broad aims when analyzed show that secondary education is supposed to prepare and supply students to various tertiary institutions of learning while at the same time equipping students with necessary skills required to live a useful life, be reliant and economically viable.

Today, unemployment is a major problem plaguing the society. This has led to a high rate of crimes in Nigeria. However, this situation could be arrested if secondary education through its aims is properly implemented. It is believed that with the proper management of diversification at secondary education level via proper teaching methodology, functional curriculum, full utilization of the few available human resources, full utilization of the few available financial resources, full utilization of the few available material resources, full utilization of available time resource, full utilization of alternative sources of revenue, provision of adequate supervision, adoption of the principle of division of labour and specialization, adoption of the principle of leadership by example, adoption of the principle of reward and punishment and moral re-orientation, students will be able to achieve the two main aims of secondary education in Nigeria.

Management of diversification at secondary education level has to do with management of various alternative means, ways, methods, resources, sources, ideas etc in order to obtain or achieve the stated goals or aims of secondary education. 
002 Educ. Res.

The aim of this paper is to take a critical study of the management of diversification of secondary education with a view to recommending ways in which it could achieve its aims.

Secondary Education in Nigeria;

Secondary education in Nigeria is aimed at preparing students for useful living within the society and for higher education FRN (2004). To actualize this, the government planned secondary education to be of 2 stages-Junior secondary and senior secondary with each having a duration of 3 years.

It is instructive to note that the junior secondary is both prevocational and academic and basic subjects are taught to enable the students acquire further knowledge and develop skills. The senior secondary school is for those who are able and willing to complete a six year secondary education.

It is important to state that the essence of the two levels or stages structure of the secondary school is to ensure that students who leave school at junior secondary level may then go into an apprenticeship system or out-of school vocational training so as to be economically functional.

The senior secondary school core curriculum is designed to broaden the students' knowledge and outlook.

These include English language, Mathematics, one Nigerian Language one alternative subjects of Physics Chemistry or Biology, one of Literature in English, History, Geography, Agricultural science or a vocational subject. The essence of the core subject is to enable a student to offer arts or science in higher institution.

Having stated the two main goals of secondary education-preparing are for higher education and for work, one can see that both aims will lead or are leading to functional education. Abraham (2011) defined functional education as education that will equip recipients with adequate scientific, vocational and cognate knowledge and competencies to compete effectively for job placements within their environment. So, functional type of senior secondary education will prepare students to develop competencies which will equip them to function within their environment and even beyond.

A proper management of the following diversifications could aid the achievement of the goals of senior secondary education in Nigeria.

(1) Full utilization of the few available human resources (Teachers)

(2) Full Utilization of the few available financial resources

(3) Full utilization of the few available material resources

(4) Full and proper utilization of the available time resource

(5) Full utilization of alternative sources of revenue to schools

(6) Provision of adequate instructional and personnel supervision in schools.

(7) Strict adherence to the adoption of the principle of division of labour and specialization

(8) Adoption of the principle of leadership by example

(9) Adoption of the principle of reward and punishment.

(10) Moral re-orientation of teachers and students.

Let us at this juncture, x-ray each of the above listed diversifications for proper understanding.

\section{Full utilization of the few available Human Resources (Teachers) in Senior Secondary Schools in Nigeria}

It is an obvious fact that the available number of teachers in our senior secondary schools is quite few. This is supported by research findings. Nwakpa (2007) found that the teacher - students ration in senior secondary schools in Ebonyi State was 1:75. We are aware of this inadequacy of teachers, but what is needed now is for the school administration or principals to ensure that few available ones are actually made to work very hard, by seeing that the school time table is fully observed using all the good approaches within his /her powers and authority.

\section{Provision and full utilization of financial resources (Money)}

It is the duty of the school principal to use the available money in his /her school to the benefit of the school. The existence of free tuition fee in Nigerian secondary schools and government poor or lack of political will in secondary education have made for little available fund in secondary schools.

The imprests to schools for running costs are very small and not even constant. The schools live on the mercy of the P.T.A levies from students. Government is only interested in paying the staff salaries. It is a known fact that education in Nigeria is poorly funded. It is actually left for the school principals to see that the little imprest given to them and the P.T.A levies are judiciously used. Money should only be used on the important items to ensure that students are taught properly. It is the duty of the government to make available adequate financial resources to schools. Principals should run theirs schools as if they are running their private businesses.

\section{Provision and full utilization of material resources}

Educational material resources are those materials that are used to achieve educational goals and objectives. These material resources include; school laboratories, equipment, classrooms, offices, play ground, toilets, teaching aids etc. 
These materials must be adequately provided by the government in order to ensure the realization of the goals of secondary education.

The relevance of material resources in secondary schools need not be over emphasized. Adeogun (1999) reported that the results of several studies conducted in developing countries have supported the educational value of the availability of text books, reading materials, the size and quality of the library and the quality of school buildings. Adeogun (1999) said that the poor quality of the out puts of Nigerian secondary schools has been traced to inadequate provision of school facilities. Furthermore Adeogun (1999) opined that private schools performed better than public schools because of availability and adequacy to teaching and learning resources.

Nwakpa (2011) maintained that adequate provision of material and human resources in secondary schools are sine qua none to effective and efficient school administration and academic performance. This he said when he found gross inadequacy of school materials in Ebonyi State public secondary schools in 2011.

\section{Full and proper use of time resources}

The time resource is the available time for school for business which is spent between 8:00pm and 2:00pm on working days. Within these periods there are official duties to be carried out by the teachers, principals and students, but the question is how adequate do we make use of this very limited resource? In majority of Nigeria Secondary Schools time is never taken seriously by the actors, the principals, teachers and students. Observations have shown that during school hour's teachers, students even principals are seen loitering about on school compound. Teachers are found in groups discussing politics and their personal issues leaving the students unattended to creating rooms for students' idleness and noise making.

For the goals and objectives of the secondary education to be achieved there should be thorough reorientation of teachers, principals and students towards time management. Time management in secondary schools is the duty of the school principals who are the life wire of their schools. Thus, they must see that the available time is judiciously and appropriately used to the advantage of the school.

\section{Full utilization of alternative sources of revenue to schools}

The need for alternative sources of revenues to schools arises out of necessity. It is as a result of inadequate provision of funds to schools by the government concerned. Every school principal must evolve several alternative sources of fund in order to see that his or her school does not collapse. There are many suggested ways or alternative ways of funding secondary education in Nigeria. One of these alternative ways has been suggested by Enyi (2001) that community direct labour could be used to erect temporary school buildings and that communities can on their own organize fund raising during their annual general meetings to financial assistance in the administration of their local school(s). While Nwakpa (2007) suggested that secondary school students should be meant to pay the sum of 1,000 for collecting school testimonial, statement of result and certificate, while Local Government. Authorities should be meant to give out 2 percent of their monthly allocation to State Secondary Education Board.

The school principal could also make use of school farms and the proceeds to make money for the school. Rent the school halls or compound to those who want to use it for ceremonies, and students crafts could be sold to make money for the school. The school could also organize fund raising in order to execute one project or the other.

\section{Provision of adequate instructional and personnel supervision}

To achieve the goals of secondary education calls for effective supervision of both instructions and personnel by the school principals. The hub of school administration is supervision. Naturally majority of human beings are very lazy and if not thoroughly supervised at work, they cannot perform. Many teachers fall under group of people described in theory $X$ of Mac-Gregor.

Nwakpa (2001) found that ineffective supervision of schools was responsible for poor student's performance in their studies. He further observed that external school supervision starts and ends in the principal's office, and that their recommendations are never carried out. The success of any business starts with strict supervision of the activities of the workers by the super ordinate. Why are we rushing private schools at the expense of public schools? Do private schools have better teaching staff than public schools? No, they don't have. The only thing they have better than public schools is supervision. They carry out strict supervision of both instruction and personnel. They see that teachers do their work on schedule despite the little pay they receive as salary. They see that teachers come to works punctually and regularly. Thus, public secondary school principals should borrow the leaf from their private schools counterparts.

\section{Strict adherence to adoption of the principle of division of labour and specialization}

At senior secondary school level, the school principals 
004 Educ. Res.

should see that teachers are allowed or given the subject the studied in the university. The idea of asking a Biology teacher to be teaching Physics or mathematics is very wrong, simply because there is no specialist to teach physics or mathematics. The principal should insist on the right thing to be done at all costs. When the right person teaches the right subject, the understanding of the subject is enhanced.

\section{Adoption of the Principle of Leadership by Example}

The Principle of leadership by example emphasizes that what you the leader wants others to do, start it for others to see. The Bible, the scripture, God Almighty says do unto others what you wish them to do unto you. As a leader, principal, you must first of all remove the log in your eyes before you can see clearly to ask another person (Teachers) to remove the speck in his eyes. For you, the principal to enforce punctuality, regularity, honesty behaviour, dedication and commitment and so on, you must have to start it, demonstrate it for your teachers to emulate. As a leader, always be on the fore front in every thing, this will make your teachers to actually do what you what them to do. Leadership entails exemplary life.

\section{Adoption of the Principle of Reward and Punishment}

The adoption of this principle in school administration will actually go a long way to aid the achievement of the goals of secondary education. It is a duty that a school principal should always do from time to time. The principal should always reward outstanding performers both teachers and students to encourage them to do more, while deviant behaviours must be punished publicly to discourage such behaviours. Thus, the principals inculcate the spirit of hard work and good behaviour in both teachers and students.

\section{Moral Re-orientation}

About the middle of the $20^{\text {th }}$ century, the teaching profession was a revered profession. Almost every body then wanted to be a teacher because of the status accorded to teachers. Obodoegbulam (2007) saw the teachers as a carrier of the culture of his society, the agent for its propagation, perpetuation and renewal, as well as architect for its changes for the better. The teacher serves as the mirror of his society. Everybody looks up to teachers for moral precept. Among all the professions, the teaching profession is the only field with the requisite skill to develop the human capital. Teaching is a deliberate and organized effort to initiate a learner into a way of thinking and behaviour as well as a core of norms, values, skills and techniques considered describable for developmental purpose (Obodoegbulam, 2007). Teaching profession holds the key to the development of society in terms of social behaviour, ethnics, norms and value, principles of every society. It is only the teacher who possesses the tool to make or remark the world. With the tool in his hand, we can turn the world into a game village or battle field, a community of illiterates or a society of civilized minds in all human societies, the essence of self examination is to give life a defined direction. To institute a just, fair and habitable society, certain acceptable standards of behaviour have to be put in place. In this regard, teachers take decisions, form habits and adopt appropriate attitudes to shape life. Teachers train their students physically, emotionally, mentally, socially, and morally. Morally they are trained to acquire those attitudes and values which will make their conducts and behaviours acceptable to other members of the society where they belong.

Based on the above, it is obvious that moral values are standards of behaviour which define what is good and therefore acceptable and what is evil and as such rejected. Moral standards in schools are set by government and to be enforced by the school administration. It is the duty of the school principals to bring to notice the moral standards in schools to both the old and new teachers and students in form of reorientation.

The high degree of moral laxity in our schools and the society at large calls for moral re-orientation in our secondary schools. Take for instance, the allowance of examination malpractice in our schools has metamorphosized into national electionary malpractice, lateness to school, absence from school, bribery and corruption in school and so on have all been exported into the larger society. This shows that every good conduct or otherwise starts from the schools by the teachers. Thus whatever behaviour the teacher allows grows and vice-versa. The importance of moral instruction needs not to be over emphasized, but should be made compulsory in all the levels of education.

\section{Curriculum Expansion and Implementation}

The need to expand the senior secondary school curriculum and implementation is necessitated by the fact that many of the products of our senior secondary schools could not fulfill the two major aims of this level of education. Some of the products of this level of education are neither employable nor admirable nor capable if wrongly admitted into tertiary educational institution.

The expansion of the programmes of senior secondary 
Nwakpa, 005

education by the West Africa Examination Council to include some entrepreneurial courses barbing, hairdressing, shoe mending etc is a well come innovations if its implementation is carried out. Nigeria is good in law making but weak in law execution. The expansion of the curriculum of this level of education is very good if the government gives her financial support to the implementation of the proprammes in terms of providing adequate teaching staff and teaching materials with the introduction of many entrepreneurial subjects, and making every student to specialize in not less than two areas, we are then sure of producing self reliant citizens. This will go a long way to reduce unemployment and crime waves in our society.

\section{CONCLUSION}

To positively achieve the aims of senior secondary schools in Nigeria, the diversifications discussed in this paper must be adopted by the concerned authorities wholesale despite its cost.

\section{REFERENCES}

Abraham NM (2011). Functional Edu., Militancy and Youth Restiveness, African J. Political Sci. and Intel. Relations 5 (10) 442-447.

Adeogun AA (1999). Sch. Plant Planning and Facilities Manag.. Lagos; Frame Unity (Nig) Ltd.

Enyi D (2001). Financing the migrant farmers children Edu. component of UBE programme. The Nig. Universal Basic Edu. J. 1 (2) 134-140.

FRN (2004). National Policy in Education Lagos in NERDC

Nwakpa P (2001). Effect of Ineffective Supervision on Academic Performance of secondary school students in Ohaozara L.G.A of Ebonyi State. Unpublished M.Ed thesis faculty of Education, Uni. of Lagos.

Nwakpa P (2007). Provision, utilization and Enhancement of Human and Financial Resources in public secondary schools in Ebonyi State. Unpublishing Ph.D thesis of the Faculty of Edu., Ebonyi State Uni., Abakaliki.

Nwakpa P (2011). An Assessment of Human and material Resources Availability in Ebonyi State Uni. staff Sec. Sch. Abakaliki; Academic Excellence 4 (1) 1-14.

Obodoegbulam AO (2007). Towards Effective Teacher Edu. in Nig. in the $21^{\text {st }}$ Century Knowledge Review: National Association for the Advancement of knowledge. 